ments were forty-one in number; and in fourteen of them portions of dust, containing kolpodæ in abundance, were boiled. Two mattresses containing kolpodæ were kept at $212^{\circ}$ for ten minutes; eight were kept at $212^{\circ}$ for five minutes; two were kept at $212^{\circ}$ for two minutes; and two were removed from the flame the moment the water indicated a temperature of $212^{\circ}$. In all these experiments the encysted kolpodæ were destroyed.

DECOMPOSITION OF AIR BY THE TISSUES.

An essay on this subject was presented to the French Academy at one of its late sittings. The author, M. Demarquay, has examined the atmospheric air in all parts of the organism in the open and closed cavities, and in the normal and diseased conditions of the system. He draws from this investigation the general conclusion that air rapidly undergoes decomposition when in contact with the tissues, oxygen is absorbed and disappears, nitrogen is left unacted on, and carbonic acid is evolved. The influence of each of these constituents of the atmosphere has been carefully examined.

\section{THE DEVELOPMENT OF THE INFUSORIA.}

Some curious observations on the development of infusoria, which certainly demand confirmation before being accepted by zoologists, have recently been published by Mr. Jas. Samuelson. It is known that in vegetable infusions exposed to the air the first forms of animalcules which present themselves are of the lowest type (monads), and these are succeeded by higher forms. This phenomenon Mr. Samuelson thinks is only explained by the conclusion that the monadine form which first appears is the earlier or larval stage of at least one, if not more of the ciliated infusoria, into which it becomes metamorphosed in the course of development. Mr. Samuelson has recorded several interesting experiments, and from some of them he concludes that the Cerco-monades are the larvæ or earlier form of the ciliated animalcules which succeed them. He desires that other experimenters should repeat his observations, for, though he himself has perfect confidence in their accuracy, he is aware of the great liability to error in such a difficult pursuit.

THE PRODUCTION OF ANIMAL HEAT.

M. Berthelot advances some views which differ from the theory of Liebig relative to the source of heat in the body. His memoir has been published in the last volume of the "Mémoires de la Société de Biologie," and may be read with advantage by physiologists. The author thinks that the changes of hydration and dehydration which organic substances undergo are entirely concerned in the production of heat, and this view he considers of the more importance from the fact that most of the alimentary substances are capable of exhibiting phenomena of this kind. He arranges these substances in three groups - (1) the fatty matters, (2) the carbo-hydrates, and (3) the albuminoid substances. The albuminoid substances are amides, and as such give rise to heat by their hydration with decomposition, and their dehydration with combination. The hydrates of carbon (sugar, starch, \&c.) produce heat by their decomposition alone, independently of all oxidation. Finally, the neutral fatty matters disengage heat by their decomposition and by simple hydration.

\section{ERECTILE TISSUE.}

According to the investigations of M. Charles Robin, this tissue has the following constitution:--1. A network of large capillaries dilated in such a manner as to form a species of blood reservoir, but having no resemblance to a true sinus. 2. Connected with this network is a series of arterioles, with thick muscular walls, and pursuing a peculiarly spiral course before they communicate with these capillaries. 3 . The venules. 4. The areolæ formed by the interlacement of the capillaries are limited by bundles of fibres, which are chiefly composed of the white and yellow elements of the elastic tissue, mingled with cell-fibres, and in some instances nerve-tubes.

THE LAMINARY MEMBRANE OF THE PLACENTA.

In a series of papers in the Archives Générales de Médecine, $\mathrm{M}$. Joulin last year gave a minute account of this structure. He considers that it is distinct from, and is therefore not to be confounded with, the chorion. It is composed of bundles of common fibres (which occasionally intersect, but are more usually parallel), fatty granules, and amorphous matter. None of the nuclei so characteristic of the structure of the chorion are to be found in it. It consists of two distinct layers-a superficial and a deep one : the former of extreme tenuity, the latter rather thick. It is devoid of proper vessels.
STRUCTURE OF THE RETINA IN REPTIIES.

Mr. J. W. Hulke, who has written an able essay in the "Ophthalmic Hospital Reports" on this subject, gives the following as the arrangement of the parts in the retina of frogs, snakes, and turtles:-1. The layer of rods and cones (bacillary layer; Jacob's layer). 2. A layer of outer granules. 3. Intergranule layer. 4. Layers of inner granules. 5. Granular layer proper. 6. Ganglionic layer. 7. Optic-nerve layer.

THE ACCOMMODATION-POWER OF THE EYE.

In a paper on the Anatomy of the Seal's Eye, published in the Jannary number of the Dublin Quarterly Journal of Science, Mr. Henry Wilson, F.R.C.S. I., revives the old theory of the action of the external muscles in altering the axis of the eye. He contends that the recti muscles by their pressure elongate the axis of the eye, and thus, by increasing the distance between the lens and the retina, in some measure provide for accommodation. He forgets that such an alteration, in order to be effective, should take place to an enormous extent (an inch or thereabouts); and that the action of the muscles would tend to shorten rather than elongate the antero-posterior diameter of the eye. His paper is full of interesting anatomical details, but it is to be regretted that he has not very carefully described the relations of the ciliary muscle.

\section{PHYSTOLOGICAL ACTION OF IRON.}

A new theory of the action of iron upon the system has been started by Herr Dr. Sasse, in a paper reported in Schmidt's Jahrbücher. This savant considers that the salts of iron replace, as it were, the blood-globules by acting as carriers of ozone. It is of no importance whether the iron be administered as an oxide, a per-salt, or a proto-salt ; for, when once it has entered the circulation, it continually takes up and gives off ozone till it is expelled from the body. Dr. Sasse concludes that we have in iron a means of promoting the process of oxidation; but we should never administer this medicine except in cases where the process of oxidation is not sufficiently energetic. He considers that iron should not be employed in tuberculosis.

\section{THE CIRCULATION IN THE LOWER ANIMALS.}

At the meeting of the French Academy on the 18th of December, M. Lacaze-Duthiers pointed out some curious facts relative to the bloodvessels of certain mollusks and zoophytes. He has found that the circulatory system of these animals is very different from that of the higher groups. 'The bloodvessels communicate with the atmosphere and with the stomach by direct apertures. Hence he concludes that it is unfair to extend to the higher animals generalizations which have been framed in accordance with the structure and functions of the lower ones.

\section{Correspontence.}

$$
\text { "Audi alteram partem." }
$$

\section{THE PATHOLOGY OF PNEUMONIA. To the Editor of THE LANCET.}

SIR, - In your issue of the 20th inst. Dr. Wilks, in a manner worthy of his high character and reputation, expresses his opinion that "Dr. Clark, by an independent investigation, may claim the merit due to an original discoverer of the true pathology of pneumonia;" but, on the strength of several striking facts and ingenious arguments, insists that my views, independently formed, were quite forestalled by the investigations of the late Dr. Addison, of Guy's. To this letter I shall next week return a full reply. Meanwhile I have somewhat to say in answer to "Vigo," who writes in a different strain.

In so far as "Vigo" has for twenty years taught that there is no such thing as an interstitial or intervesicular exudation in pneumonia-for that is the point of the question at issue* and in so far as he has made that knowledge his own by personal investigation, he deserves, and should have, such honour

* The mere doctrine that red hepatization is caused by the deposit of lymph in the air-cells was first taught by Andral in his Clinique Médicale; in his Path. Anat. he held that
not to intra-cellular exudation. 
as is due to the teacher of a fundamental truth at a time when it was either positively or implicitly denied in every known treatise on the subject. But when, by a stroke of audacity on the one hand, and a touch of finesse on the other, he makes it appear that the answer to the question is not a matter of doubt, and then proceeds to poison the sources from which alone proofs of the contrary can be drawn, he commits an offence which is at once fatal to fair discussion and unpardonable in one who claims truth to be the object of his criticism.

The claim made is to priority in demonstrating the absence of an intervesicular structural product in pneumonia, the impossibility of its occurrence, and the fact that all the structural elements of the pulmonary alveolus are involved in the disease "Vigo" remarks that the unopposed advancement of such a claim is likely to bring on English physiology and medicine the ridicule of scientific Europe, because he himself has taught these views for twenty years; because they are nowhere doubted except in works of Medicine many of which "partake of the character of advertisements," and cannot be appealed to for judgment; and because no modern respectable histologist asserts the presence of an intervesicular areolar tissue in the lung.

This phrase "scientific Furope," if it means anything beyond a euphuism, can mean only those persons who have investigated the pathological anatomy of pneumonia: for it is nowhere a characteristic of scientific men to ridicule what they do not understand; and if it were, the ridicule of persons knowing little or nothing of the subject at issue would be absurd. Now, Sir, with one or two apparent exceptions, to be specially dealt with in my next letter, I am prepared to prove that every one of those observers to whose works I have had access has either directly or by implication taught the existence of an interstitial or intervesicular exudation in some form of pneumonia. If then the ground upon which "Vigo" fears the ridicule of "scientific Europe" be the denial of this exudation because such denial is superfluous, that ground is wholly cut from beneath his feet.

Writers on normal histology generally pass over in silence the relation of the wall of the palmonary alveolus to the structural products of pneumonia; and when they do speak of it, it is in such a manner as either to leave their meaning obscure or to admit of a double interpretation. But $I$ have before me the work of Charcot on Chronic Pneumonia, published in 1860 ; and in this work Robin, pronounced by his antagonist Virchow to be the most accomplished histologist of France, expresses an opinion upon this point which cannot be misunderstood. In a description of the drawing, executed by Robin, which accompanies Charcot's book, an amorphous matter is represented as "filling the alveoli and their interstices;" and in the pathological part of the body of the work, written or inspired by the same histologist, the intervesicular spaces are spoken of (page 15) as having doubled or tripled their thickness, and as containing fusiform cells or connective tissue. The same idea of structural products lodging in the wall of the alveolus, or between the alveoli, will be found embodied at page 56, and in sundry parts of the paper by Isambert and Robin on Congestive Carnification (Mém. de la Soc. de Biol., 1855, p. 3). Thus, then, though Robin may not-but for aught that I know to the contrary he may-positively teach the existence of an intervesicular areolar tissue in the lung, neither can he nor his pupils discuss the subject of pneumonia without speaking of its structural products as lodging in the wall of the alveolus, or between the alveoli. Now these are two of the current views on this subject the accuracy of which I emphatically deny.

As the extracts which I have made from the works of various observers to prove their tacit or expressed belief in the existence of an intervesicular exudation in pneumonia are too voluminous for admission into your pages, it must suffice to give the chief references now, whilst I promise to publish the quotations in full hereafter. But I shall make two exceptions : one from the article on Pneumonia by Dr. Williams in the Library of Medicine, and the other from a chapter on the same subject in the Manual of Pathological Anatomy by Drs. Sieve. king and Handfield Jones.

The article of Dr. Williams was published, it is true, in 1840 , but then the views therein expressed upon the subject of intervesicular exudation are incidentally endorsed in various parts of the last edition of his Principles of Medicine.

Here is what Dr. Williams says:- "From many minute examinations which we have made we have been long convinced that the granulations of hepatized lungs contain no appreciable quantity of viscid mucus, but that they are probably portions of vesicles and minute tubes, with their tissues dis- tended, with an interstitial deposit of lymph, and occasionally having the same matter in their interior...... But hepatized lungs do not always present this granulated appearance: sornetimes there is a uniform condensation of a deeper red than usual..... We are disposed to view this...... kind of hepa. tization as the result of inflammation confined more to the plexus of vessels and intervesicular tissues, and less affecting the membranes forming the cells..... The recent researches of Hourman and Dechambre on the pneumonia of the aged confirm this view...... Having been the first to describe the latter as a separate form of pneumonia, we prefer the term intervesi. cular."-Library of Melicine, vol. iii., p. 138.

Here is what Drs. Sieveking and Handfield Jones say :In pneumonia "the exudation takes place both into the inter. stitial and into the intervesicular spaces according to the laws regulating the exosmosis of inflamed vessels. The condensa. tion that takes place in the tissues in pneumonia, and the form of deposit, is of a very different character from that occurring in tubercular disease, and would alone serve to prove that the exudation takes place both within and external to the air vesicles. The consolidation of pneumonia does not produce any material change in the form of the vesicular structure, which continues to present its globular form even in the third stage. Now, if the exudation took place exclusively within the vesicles their mutual compression would produce poly. hedral forms, while the exclusive effusion external to them would not only obliterate them but entirely destroy all trace of them. As it is, we continue to trace their form because, the extra- and intra-vesicular effusions being tolerably uniform, the pressure is equable."-Path. Anatomy, p. 425.

Here, lastly, follow a few references to the works of recognised observers, who tacitly or expressly teach the existence of an intervesicular structural exudation in pneumonia : Lebert: Anat. Path., vol. i., pp. 644, 647. Grisolle: Traite de la Pneum., 2nd edit., pp. 15, 19. Walshe: Diseases of the Lungs, 3rd edit., pp. 350, 360. Rokitansky: Path. Anat. vol. iv., p. 90 , to be read along with what is said of tubercle at p. 102. Hasse (who, however, is very close upon the exact truth) : Path. Anat., pp. 220, 288. Niemeyer (and Virchow as quoted by him): Pathol. Interne, traduc. de l'Allemand, t. i., p. 240. Aitken: Prac. of Med., 2nd edit., vol.ii., p. 831 also author of an original memoir on Pneumonia. Gross Path. Anat, p. 418. Betz: Bullet. des Acad., 1850. Foerster: Path. Anatom., art. Pneumonia Int. Cornil: Pneumon Parenchym., Rec. des Travaux de la Soc. Méd. d'Observat. fas. 12, p. 750. Gunsburg: Die Path. Gewebelehere, vol. i. p. 59. Wedl: Path. Histology, p. 251. Merchie: Leçons Cliniques, Jour. de Méd. de Brux., Oct. 1864.

Perhaps "Vigo" may now find it convenient to reply that these are not respectable authorities, and that their works partake of the character of advertisements. If he will not say as much of his countrymen and contemporaries, Drs. Williams, Sieveking, and Handfield Jones, whose views I have quoted at length, then why, in the name of honour and consistency, has he, so long in possession of an important truth, abstained from resenting its vioiation by these observers? Had he not greater reason to speak to them than to me. Surely, Sir, it is much more ridiculous to claim credit for a discovery which has no existence, than-to say the least-for the clear statement and confirmation of a truth which has bitherto been obscurely expressed and imperfectly understood.

I might now proceed to show that "Vigo" has missed the point of the question at issue, and to define the part he has played in this discussion; but I have already exhausted more than my share of your space, and so must needs terminate this part of my subject, and leave "Vigo" for the present under the protection of his mask.

I have the honour to be, Sir, your obedient servant, ANDREW ClaRK.

Montague-place, Russell-gquare, Jan. 30th, 1866.

\section{DR. MOREHEAD ON CHOLERA.} To the Editor of 'THE LaNCET.

SIR,-I observe that Dr. Morehead objects to two statements of mine in reference to cholera. Permit me to say a few words in reply.

1. Dr. Morehead says that my statement that "general feebleness of health gives no predisposition" to cholera is a * I regret that these references are so few, and in some respects so im. perfect; but I have been prevented from extending or completing them by labour in this direction. Unacquainted with German, references to works in that language are made at second havd. 